Purdue University Purdue e-Pubs

Libraries Research Publications

3-1-1999

\title{
Campaign Finance Information: An Overview of Print and Internet Resources
}

Bert Chapman

Purdue University, chapmanb@purdue.edu

Follow this and additional works at: http://docs.lib.purdue.edu/lib_research

Chapman, Bert, "Campaign Finance Information: An Overview of Print and Internet Resources" (1999). Libraries Research Publications. Paper 51.

http://docs.lib.purdue.edu/lib_research/51

This document has been made available through Purdue e-Pubs, a service of the Purdue University Libraries. Please contact epubs@purdue.edu for additional information. 


\section{Campaign finance information: an overview of print and Internet resources}

\author{
B ert Chapman
}

\section{The author}

Bert Chapman is Government Publications Coordinator/

Reference Librarian and Assistant Professor at Purdue

University, West Lafayette, Indiana, USA.<chapmanb

@ purdue.edu>

\section{Keywords}

Development, Fund raising, Information systems,

Political parties, USA

\section{Abstract}

Revelation of controversial fundraising practices by the Clinton-Gore reelection campaign in 1996 and continuing controversy over proposed campaign finance reform legislation has brought this subject into public focus and discussion. This article provides an overview of key recent developments in campaign finance accompanied by coverage of literature and Web sites produced by scholars, government agencies, and participants in the ongoing debate over campaign finance and its role in the American political process.
Reference Services Review

Volume $27 \cdot$ Number $3 \cdot 1999 \cdot$ pp. 300-312

c MCB University Press · ISSN 0090-7324

\section{Introduction}

Running for public office and remaining in office once elected are important features of A merican and all democratic societies. $C$ andidates for public office in the U SA, though, can spend significant financial resources running for election and reelection. The impact of this need for political fundraising and its influence on the electoral process and public policymaking is the source of often-contentious debate.

$A$ recent US Senate investigation revealed that D emocratic $\mathrm{N}$ ational $\mathrm{C}$ ommittee fundraising increased by 300 percent between 1992 and 1996 (U S C ongress, 1998). Federal Election C ommission statistics demonstrate that the number of political action committees (PAC s) has skyrocketed from fewer than 500 in 1974 to over 4,000 in the mid-1990s (US Federal Election C ommission, 1992), expenditures for U S H ouse and Senate races have risen from nearly $\$ 500$ million in 1988 to nearly $\$ 800$ million in 1996, PAC contributions to D emocratic and Republic congressional candidates increased from approximately $\$ 190$ million to $\$ 220$ million between 1994 and 1996, and contributions to both political parties' national committees in 1996 from federal and nonfederal sources approached $\$ 550$ million (US F ederal Election Commission, 1997).

Attempts to deal with real or perceived problems in campaign finance have occurred throughout American political history. The basis for modern campaign finance legislation and governmental regulation is the Federal Election C ampaign Finance Act ( F E CA) of 1971 and amended in 1974. Provisions of this legislation include requiring reports from political committees and candidates about individual contributors, setting spending limits for federal campaigns, providing federal funding for national political party conventions, presidential primaries, and presidential elections, and establishing the F ederal Election Commission to regulate campaign spending. Federal or public funding for congressional campaigns was rejected by $\mathrm{C}$ ongress in enacting this legislation[1].

These and other provisions of F ECA govern U S campaign finance activity until the present. $\mathrm{H}$ owever, the ability of the federal government 
to achieve unfettered regulation of campaign finance was restricted by the U S Supreme C ourt on 30 January 1976. T hat day the Court issued its ruling in the case B uckley v. Valeo which was a suit brought by various individuals, political candidates, and groups challenging the constitutionality of FECA provisions limiting individual and group contributions to political candidates. T hose bringing the suit charged that such expenditure restrictions violated $\mathrm{F}$ irst A mendment speech and association rights and $\mathrm{F}$ ifth $\mathrm{A}$ mendment equal protection principles.

The Supreme Court ruled on behalf of the plaintiffs saying that the $F$ irst A mendment protected political association and political expression. In its unanimous 9-0 ruling the court went on to rule that spending limits for individual candidates were unconstitutional as were restrictions on the amount of money candidates could contribute to their own campaigns arguing:

The provisions of the $F$ ederal Election $C$ ampaign Act of 1971 ( 18 U SC S 608) imposing limitations upon the giving and spending of money in political campaigns for federal offices cannot withstand attack under the First A mendment on the ground that such provisions merely regulate conduct, with only an incidental effect on speech and association; the Act's contribution and expenditure limitations both implicate fundamental First A mendment interests, although its expenditure ceilings impose significantly more severe restrictions on protected freedoms of political expression and association than do its limitations on financial contributions ( B uckley v. Valeo).

The B uckley v. Valeo ruling restricted but did not limit the scope of campaign finance reform legislation during the next two decades. The continuing and relatively consistent rise in campaign finance expenditures and the perceived demand from public opinion for curtailing such expenditures led to several unsuccessful attempts to push campaign finance reform legislation through Congress during the 1980s and 1990s (Rubin, 1997, pp. 795-6).

$T$ hese attempts to promote various versions of campaign finance reform stemmed from factors as diverse as genuine desire to restrict campaign finance expenditures and concern over the alleged negative effects of PAC s on the electoral and policymaking process. C ampaign finance reform advocates do not necessarily adhere to strict partisan or ideological boundaries as the proposed M CC ain-F eingold legislation of the 105th Congress indicates.

$T$ his effort by Senators John M cC ain (R-AZ) and Russell Feingold (D-WI) sought to ban "soft money" or unrestricted donations to political parties for party-building activities and place restrictions on issue-oriented advertisements which support individual candidates although they are not supposed to (D oherty, 1998). A rguing for this legislation, F eingold asserts, "T he biggest threat to our democracy still comes from this out of control campaign finance system" (C ongressional R ecord, 1998, p. S10147).

M cC ain, during Senate floor debate on this issue and legislation, contends:

$U$ ntil we recognize the futility of procrastination, the money chase in this hallowed Capitol, the debasement of the White $\mathrm{H}$ ouse, the selling of trade missions, the never-ending series of fundraising scandals that leads the public more and more to believe that elected officials only represent monied special interests will not end.

Congress can and must and will change this system. If we do not act, there will be more scandals, both parties will be further tainted by this system, no one will be left unscathed, and that fact will force this body to do what is right (Congressional Record, 1998, p. S10176).

$\mathrm{C}$ ritics of proposed campaign finance reform initiatives such as $\mathrm{M} \mathrm{CC}$ ain-F eingold stress the importance of adhering to the B uckley v. Valeo ruling and the potential problems of allowing greater governmental regulation of electoral activity. The most prominent of these critics is Senator M itch M CC onnell (R-KY) who stresses the importance of $\mathrm{F}$ irst A mendment protections in the existing system and the Supreme Court's decision in B uckley v. Valeo:

... the $C$ ourt said spending is speech and the first amendment applies to individuals, groups, candidates, and parties, as well as to the press (Congressional Record, 1998, p. S1043).

$\mathrm{M} \mathrm{cC}$ onnell went on to warn against what he considers to be ill-advised governmental attempts to regulate political activity:

It is naive in the extreme to expect that people don't want to have some impact on a political process which takes 30 to 40 percent of their money every year - paying taxes is not exactly a voluntary act - and spends it on what it wants to. 
What kind of country would we have if all of these people in our land were unable to influence the political process? We would have an unrepresentative democracy, a $\mathrm{G}$ overnment run by elitists who want to shut everybody up. Fortunately, M r President, the courts are never going to allow that to happen. The Senate is never going to allow it to happen, because we are not going to go down the road of regulating people out of the political process because we don't like either the quantity or the quality of their speech....T he first amendment doesn't allow us the latitude to categorize certain kinds of speech as offensive and other kinds of speech as laudable. So that is at the core of this debate (C ongressional R ecord, 1998, pp. S1043-44).

This controversy is likely to continue for the foreseeable future. Although campaign finance is an important factor in electoral political activity, money is not the only player in determining election results. Research in this area demonstrates the role played by factors such as candidate quality, differences in the quality of challengers by office sought, strategic decisions made by candidates, the importance of local and personal factors as opposed to national issues, how candidates spend money, their objectives for such campaign spending, locally prevailing economic conditions, and voter understanding of election information also need to be considered in determining the reasons for the success or failure of individual political campaigns[2].

W hatever views one takes on the subject of campaign finance and whether or not reform is required, there is an ample body of literature presenting diverse and often contradictory perspectives to inform and shape individual opinion. This literature takes the form of government publications, journal articles, books, and Internet resources from political parties, politicians, policymakers, PAC s, interest groups, and scholars. T hese materials can help individuals gain an enhanced understanding of this complex issue and its influence on the A merican political process at the close of the twentieth century.

\section{Notes}

1 See A.J. Rubin (1997), "History of changes in campaign law" , Congressional Quarterly Weekly Report, Vol. 55, 5 April, pp. 794-6 for a succinct historical synopsis of major federal campaign finance legislation.
2 See P. Squire (1995), "Candidates, money, and the voters - assessing the state of congressional elections research", Political Research Quarterly, Vol. 48 No. 4, pp. 891-917; and Gross, D.A., Shields, T.G. and Goidel, T.G. (1997), "Campaign finance reform and the 1994 congressional elections" , Policy Studies Journal, Vol. 25 No. 2, pp. 215-34, for coverage of trends in campaign finance research.

\section{References}

Doherty, C.J. (1998), " M cCain-Feingold again hobbled by little impetus for change", Congressional Quarterly Weekly Report, Vol. 56, 21 February, p. 417.

"Mr. Feingold" (1998), Congressional Record, 105th Cong., 2nd sess., Vol. 144 No. 119, 10 September, p. S10147, Washington, DC.

"M r. McCain" (1998), Congressional Record, 105th Cong., 2nd sess., Vol. 144 No. 119, 10 September, p. S10176, Washington, DC.

"M r. McConnell" (1998), Congressional Record, 105th Cong., 2nd sess., Vol. 144 No. 16, 26 February, p. S1043, Washington, DC.

"M r. M cConnell" (1998), Congressional Record, 105th Cong., 2nd sess., Vol. 144 No. 16, 26 February, p. S1043-44, Washington, DC.

Rubin A.J. (1997), "History of changes in campaign law", Congressional Quarterly Weekly Report, Vol. 55, 5 April, pp. 794-96.

Sorauf, F.J. (1992), Inside Campaign Finance: Myths and Realities, Yale University Press, New Haven, CT, p. 66.

United States, Federal Election Commission (1997), Annual Report 1996, Washington, DC.

United States Congress, Senate Committee on Governmental Affairs (1998), Investigation of Illegal or Improper Activities in Connection with 1996 Federal Election Campaigns: Final Report... Together with Additional and M inority Views, GPO, Washington, DC, 1:33.

[5]US Supreme Court (1976), Buckley v. Valeo, 424 US 1, Washington, DC.

\section{Bibliography}

\section{Government publications}

C antor, J.E . (1997), Congressional Campaign Spending: 1976-1996, L ibrary of C ongress, Congressional Research Service, Washington, DC , 6p., 97-703 G OV. A vailable on Senate Rules Committee WWW page at <http:// www.senate.gov/-rules/crs/97-703.pdf

This report provides summary data on congressional campaign expenditures from 1976-1996. It includes aggregate expenditure figures for incumbents and challengers, $\mathrm{H}$ ouse and Senate race breakdowns, general election candidates, 
and partisan breakdowns. Figures in some tables are adjusted for inflation.

C antor, J.E. (1997), Soft and $H$ ard M oney in C ontemporary E lections: W hat F ederal $L$ aw $D$ oes and $D$ oes $N$ ot R egulate, Library of $C$ ongress, C ongressional Research Service, Washington, D C , 6p., 97-91 G OV. Available on Senate Rules committee WW W page at http://www. senate. gov/rules/crs/ 97-91.pdf>

This report discusses campaign finance characteristics which are covered and not covered by federal law. A nalysis begins by focusing on federal regulation of hard money expenditures such as advocating the election of a particular candidate and requiring candidates to file financial activities reports with the FEC. The Supreme C ourt ruling B uckley v. Valeo striking down limits on campaign expenditures is discussed as are independent expenditures of money by individuals and organizations not controlled by candidates for elected office. The final section covers soft money activity which is not controlled by federal law. A reas covered under this heading include corporate and labor union activity such as establishing political action committees (PACs) to promote their interests, party soft money which emphasizes grassroots party development, issue advocacy by diverse interest groups focusing on specific issues, and lobbying by tax-exempt organizations.

C ontrubis, J. and L ee, M .M . (1997), TheU se of U nion D ues for Political Purposes: A L egal A nalysis, Library of $C$ ongress, $C$ ongressional Research Service, Washington, DC, 16p., 97618A. A vailable on Senate Rules C ommittee WWW page at <http://www. senate. gov/rules/ crs/97-618.pdf>

T he active support given by organized labor to President Clinton's 1996 reelection campaign proved to be a controversial issue in the aftermath of that election. T his report provides legal background and analysis on the use of union members' funds for political activity. After opening with a contextual introduction, The U se of $U$ nion $D$ ues covers topics such as labor union activity under the Federal Election C ampaign Act of 1971, the background of union security agreements concerning the status of unions with individual companies, U S Supreme C ourt decisions concerning the political use of compulsory union dues, and overviews of 105th C ongress legislation on labor union political activity. A digest of proposed 105th Congress legislation on this subject concludes the report.

Contrubis, J. and Wolfe, M.A. (1998), Soft $M$ oney in Campaign $F$ inance R eform, Library of $C$ ongress, $C$ ongressional Research Service, Washington, DC , 15p. Issue B rief 96036. A vailable on Senate Rules Committee WWW page at <http://www.senate.gov/rules/ crs/96036.pdf>

This C ongressional Research Service (CRS) report covers the role of "soft money" in campaign finance. Soft money is described as funds used in elections for party building and grassroots activities that are not subject to F ederal Election $\mathrm{C}$ ampaign Act or $\mathrm{FEC}$ regulations. $T$ he report opens with coverage of recent congressional campaign finance proposals, then proceeds to define the use of hard and soft money in federal elections, corporate and labor union use of soft money, and the use of soft money to advocate the issue stances of interest groups. References to relevant court cases dealing with these areas of campaign finance are also included.

M askell, J.H . (1996), L obbying R egulations on $\mathrm{N}$ on-P rofit $\mathrm{O}$ rganizations, Library of Congress, Congressional Research Service, Washington, D C, 9p., 96-809A. A vailable on Senate Rules $C$ ommittee WW W page at $<$ http://www.senate.gov/rules/crs/96-809. pdf $>$

This report provides a succinct summary of federal lobbying regulations on nonprofit organizations as defined by $T$ itle 26 Sections 501 (c)(3) et. seq. of the U S Code. Entities following within these categories include charitable organizations whose organization and operations are exclusively religious, charitable, scientific, and educational in intent, civic organizations whose intent is promoting social welfare, labor organizations and trade associations, and organizations receiving federal grants and loans. Restrictions on the use of federal funds by such organizations are chronicled as are lobbying disclosure requirements. 
U S C ongress, Committee on H ouse O versight (1996), Campaign F inance R eform A ct of 1996: $R$ eport Together with $M$ inority $V$ iews ( to A ccompany H.R. 3760), GPO, Washington, DC, SuD ocs no. Y 1.1/8:104-677. Item: 1008-C. 70p.

This report contains the text of this committee's report on H.R. 3760 whose purpose was to amend the F ederal Election C ampaign Act of 1971. The report is divided into four titles covering categories such as restoring individual controls over elections, strengthening political parties, disclosure and enforcement, and general provisions. Specific provisions of this proposed legislation include requiring the majority of U S H ouse of Representatives campaign funds to come from individuals living in that congressional district, allowing political parties to carry over funds from previous elections, and requiring the F ederal Election Commission (FEC) to make campaign disclosure information available on the Internet within 24 hours after its receipt.

$M$ inority views were expressed by committee D emocrats headed by Rep. Vic F azio (D -CA). T hey contend that H.R. 3760 perpetuates the flow of unregulated soft money to political parties, that it encourages negative campaigning, and that they don't provide the FEC with enough resources to meet its added responsibilities under this legislation.

U S C ongress, Committee on H ouse O versight (1996), Influencing Elections: Political A ctivity of $L$ abor U nions, GPO, Washington, DC, SuD ocs no. Y 4.H 81/3:EL 2/21. Item: 1018-A. ISBN 016-052888-7. 153p.

$L$ abor unions have exerted various levels of political activity throughout A merican political history. This $21 \mathrm{M}$ arch 1996 hearing examines recent and historical political activity by US labor unions. Testimony on this often-contentious subject was provided by attorneys T homas D urbin and Paige Whitaker of the C ongressional Research Service's A merican $L$ aw D ivision, Rutgers U niversity economics professor L eo Troy, $\mathrm{N}$ ational Right to Work Committee President R eed L arson, $\mathrm{H}$ arry Beck, the initiator of a lawsuit against compulsory union contributions for political purposes which culminated in a favorable 1988 U S Supreme $C$ ourt ruling against this practice, $\mathrm{C}$ harlene $\mathrm{H}$ aar of the E ducation Policy
Institute, and $\mathrm{C}$ atholic $\mathrm{U}$ niversity of A merica L aw School professor $M$ arshall Breger.

U S C ongress, H ouse C ommittee on G overnment R eform and O versight (1998), Federal E lection Commission E nforcement A ctions: Foreign Campaign Contributions and 0 ther FECA V iolations, GPO, Washington, DC, SuD ocs. no.: $Y$ 4.G 74/7:EL 2/10. Item: 1016-A. ISBN 0-16057054-9. 298p.

The aftermath of the 1996 presidential election produced significant controversy over contributions made by foreign nationals to President Clinton's reelection campaign. T his $31 \mathrm{M}$ arch 1998 hearing sought to determine whether these contributions constituted violations of the Federal Election Campaign Act (FECA). Witnesses testifying at this hearing include $F$ ederal Election Commission (FEC) Vice C hairman Thomas E. Scott, FEC G eneral C ounsel Lawrence M . N oble, and other FEC attorneys. Topics covered include FEC investigation of the illegal financial contributions of $G$ erman citizen Thomas $\mathrm{K}$ ramer to both the $\mathrm{D}$ emocratic and Republican Parties, FEC responses to committee members' questions, and receipts and correspondence from a F lorida fundraiser for the D emocratic $\mathrm{N}$ ational Committee.

U S C ongress, H ouse C ommittee on G overnment R eform and O versight (1998), J ohnny Chung: $\mathrm{H}$ is $U$ nusual $A$ ccess to the $W$ hite $H$ ouse, $H$ is Political $D$ onations, and R elated $M$ atters, GPO, Washington, DC , SuD ocs. no. Y 4.G 74/7:AC 2/11. Item: 1016-A. ISBN 0-16056278-3. 1192p.

This 13-14 N ovember 1997 hearing examined the controversy surrounding a $\$ 50,000$ donation by Johnny $C$ hung to the $D$ emocratic $N$ ational Committee in M arch 1995 and whether this enabled $C$ hung to gain access to President $\mathrm{C}$ linton for his $\mathrm{C}$ hinese business partners. Witnesses appearing at this hearing include First L ady H illary Rodham C linton's former secretary $M$ argaret W illiams and D eputy Assistant to the President for A ppointments and $\mathrm{Scheduling} \mathrm{N}$ ancy $\mathrm{H}$ ernreich. Transcript contents al so include depositions of former presidential political advisor Dick M orris and documentary submissions such as W hite $H$ ouse visitor logs, $\mathrm{D}$ emocratic $\mathrm{N}$ ational C ommittee 
correspondence, check receipts, and gifts exchanged between $\mathrm{C}$ hung and the $\mathrm{C}$ lintons.

U S C ongress, H ouse Committee on the Judiciary (1997), $F$ ree $S$ peech and C ampaign Finance R eform, G PO, Washington, DC, SuD ocs. no. Y 4.J 89/1:105-15. Item: 1020-A. ISBN 0-16055361-X. 185p.

T his 27 F ebruary 1997 hearing seeks to place public and political discussion of campaign finance reform within the context of the F irst A mendment as evidenced by the US Supreme C ourt's 1976 ruling in B uckley v. Valeo applying F irst A mendment protections to campaign finance. Individuals testifying for this hearing and presenting supplementary materials into its transcript include the A merican C ivil Liberties U nion's E executive D irector I ra G lasser, G ene $K$ arpinski of the U S Public Interest Research $G$ roup, Representative Barney $F$ rank (D-M A), Senator $M$ itch M CC onnell (R-K Y), D avid $M$ ason of the $H$ eritage $F$ oundation, and $C$ apitol U niversity L aw School professor Bradley Smith.

U S C ongress, Senate C ommittee on G overnmental Affairs (1998), I nvestigation of I llegal or I mproper A ctivities in Connection W ith 1996 Federal E lection C ampaigns: Final R eport... Together with $A$ dditional and $M$ inority $V$ iews, 6 vols., GPO, Washington, DC , SuD ocs no. Y 1/1/5:105-167/N. 1-6. Item: 1008-C. 9575p. A vailable electronically at $<\mathrm{http}$ ://www.senate. gov/-gov_affairs/sireport.htm>

$T$ his report contains the findings of the U S Senate's investigation into 1996 federal election fundraising activities with primary emphasis being placed on D emocratic Party and Clinton/G ore campaign fundraising. Chaired by Senator $F$ red $T$ hompson (R-T N), this report documents the extent to which the C linton/G ore campaign sought to raise funds for its reelection campaign from a variety of domestic and international sources. The roles played in C linton/G ore campaign financing by individuals as diverse as Johnny C hung, John $\mathrm{H}$ uang, Roger Tamraz, C harlie Trie, M aria $\mathrm{H}$ sia, and American Indian gaming interests are presented. D ocumentation is also provided in the form of letters, travel receipts, White H ouse and D emocratic $\mathrm{N}$ ational Committee (D N C) documents, correspondence, and legal documents such as sentencing agreements.
D espite this ample quantitative material, the committee report also mentions that it was unable to obtain information from 35 witnesses due to their invoking $F$ ifth A mendment privileges, that ten potential witnesses fled the US, and resistance from the White $\mathrm{H}$ ouse, D N C, and nonprofit organizations playing significant roles in this campaign.

Investigation recommendations include a call for the Attorney G eneral to appoint an independent counsel for further investigation of this case, that those ineligible to vote be precluded from making contributions to federal candidates, and increased penalties for knowingly accepting illegal campaign contributions. Supplemental views were filed by selected committee majority members including Senators Thompson, Susan Collins (R-M E), Arlen Spector (R-PA), and Robert Bennett (R-UT). $M$ inority views on report findings were filed by committee $D$ emocrats including Senator John G lenn (D-OH), Richard D urbin (D-IL), and Robert Torricelli (D-NJ).

U S C ongress, Senate Committee on Rules and Administration (1996), Campaign Finance R eform Proposals of 1996, G PO, Washington, DC, SuD ocs no. Y 4.R 86/2:S.H RG . 104-542. Item 1046-B. ISBN 0-16-053764-9. 735p.

This report contains the contents of hearings between F ebruary and M ay 1996 on legislation pertaining to Senate election campaign financing introduced during the 104th Congress. I ssues addressed by this proposed legislation include providing for voluntary spending limits by political campaigns, partial public financing of Senate elections, and limiting contributions by multi-candidate political committees. Witnesses testifying at these hearings represent politicians, interest group representatives, and scholars and adhering to diverse and often conflicting views on the merits and demerits of these proposed legislative remedies. T hose testifying include Senators $D$ ianne F einstein (D-CA), John M CC ain (R-AZ), and Paul Wellstone (D-M N), C ommon C ause President Ann $\mathrm{M}$ cB ride, Public C itizen President Joan C laybrook, L eague of Women Voters President Becky C ain, James Bopp of the Terre H aute, Indiana-based F ree Speech C oalition, Inc., Thomas $\mathrm{M}$ ann of the Brookings Institute, former Republican $\mathrm{N}$ ational Committee 
Campaign finance information Bert Chapman

$\mathrm{C}$ hairman $\mathrm{H}$ aley Barbour, and $\mathrm{N}$ orman Ornstein of the American Enterprise Institute.

U S Federal Election Commission (1996), Campaign Finance Law 96: A Symmary of State Campaign $F$ inance $L$ aws with $Q$ uick R eference Charts, Federal Election Commission, Washington, DC, SuD ocs no. Y 3.EL 2/3:2-10/96. Item 1091-A. ISBN 0-16-048656-4. Various paginations.

Issued every other year, this source summarizes state campaign finance laws. Q uick reference charts in the first part of this work cover topics such as campaign finance law filing requirements, contribution, solicitation, and expenditure limitations, and states with special tax or public financing provisions for campaign finance. The heart of $C$ ampaign $F$ inance $L$ aw 96 provides analytical summaries of state campaign finance legislation with references to relevant authorizing statutes. Reporting and post-election campaign requirements are included in these entries along with listings of state agencies responsible for enforcing electoral campaign activity.

U S Federal Election Commission (1997), Federal E lection Campaign Laws Compiled by the Federal E lection C ommission, Federal Election Commission, Washington, D C , SuD ocs no. Y 3.EL 2/3:5 C 15/2/997. Item 1091-A. 143p.

This compendium covers federal election campaign laws from titles $2,18,26,39$, and 47 of the U S Code. Specific statutory provisions covered include political committee organization and registration requirements, Federal Election Commission (FEC) powers, dollar limits on campaign contributions, public fund payments to eligible presidential candidates, criminal penalties for kickbacks and illegal payments, FEC reports requiring congressional submission, tax rules for political organizations, and broadcasting regulations.

U S Federal Election Commission (1998), U sing the Internet in Election $O$ ffices, F ederal E lection Commission, Washington, D C, SuD ocs no. Y 3. EL 2/3:18/16. Item 1091-A. 98p. plus appendices.

This report in the FEC's Innovations in E lection Administration series provides guidance on how government election offices can use the
Reference Services Review

Volume $27 \cdot$ Number $3 \cdot 1999 \cdot 300$ - 312

Internet. It opens with general information about the Internet and guidance about setting up a Web site. L ater topics covered include creating an election agency Web site, the use of the Web for campaign finance disclosure information, and providing voter registration and other services via the Web. A ppendices feature information on Web plugins, state developments in electronic election information disclosure, a proposed model electronic reporting law, Web sites of state and selected local election offices, and e-mail addresses for these offices.

\section{Books}

Biersack, R., H errnson, P.S. and Wilcox, C. (Eds) (1994), R isky B usiness?: PAC D ecisionmaking in Congressional Elections, M .E. Sharpe, Armonk, NY, ISBN 1-56324-295-8, 313p.

This detailed study of PAC $s$ and how they make decisions about supporting candidates in congressional elections is based on interviews with PAC leaders. R isky B usiness is divided into three parts covering lead PAC $s$, institutionalized PACs, and "mom and pop" PACs. Lead PACs are establishment organizations regarded as opinion leaders in the PAC industry. Organizations such as the AF L-CIO's Political Education Committee and the Business and Industry Political Action Committee fall into this category. Institutionalized PAC s include organizations such as the $\mathrm{N}$ ational $\mathrm{E}$ ducation Association, $\mathrm{N}$ ational Association of Realtors, $\mathrm{N}$ ational A bortion Rights Action L eague, and $\mathrm{N}$ ational $R$ ight $L$ ife. T hese are organizations noted for their elite status constituted in making the majority of PAC contributions to congressional candidates, their highly developed organizations, and use of elaborate rules to orient their political involvement. "M om and pop" PAC S are generally smaller organizations with diverse political and legislative objectives where it is possible for a single person to make contribution decisions. Organizations listed as following into this group include the $\mathrm{N}$ ational F ederation of $\mathrm{F}$ ederal $\mathrm{E}$ mployees, $\mathrm{N}$ ational Air Traffic Controllers, Association of A merican Publishers, and single-issue PAC s for issues such as abortion and the environment.

Clawson, D., N eustadtl, A. and Scott, D. (1992), M oney Talks: Corporate PACS and Political Influence, Basic Books, N ew York, ISBN 046502-680-X, 272p. 
This study is a critical examination of the role corporate political action committees (PAC s) play in the political process. Topics addressed within this work include fundraising, the internal structure of corporate PAC s, using campaign contributions to increase access to members of $C$ ongress, ideological and pragmatic goals of corporate political contributions, and how corporate PAC directors view their organizations' roles within the political process. Additional coverage and assessment is provided on desirable objectives for campaign finance reform legislation and arguments for and against public financing of election campaigns.

An appendix features charts of selected corporate PAC contributions to D emocratic and Republican congressional race challengers between 1976 and 1988.

Corrado, A. (1992), Creative C ampaigning: PACS and the Presidential Selection Process, Westview Press, Boulder, C O, ISBN 0-8133-1450$X, 286 p$.

This study analyzes how the F ederal Election $C$ ampaign Act has failed by making presidential elections more time-consuming and creating a climate conducive to the growth of PACs. An introductory chapter describes the emergence of candidate PAC s and campaign finance regulation. L ater chapters describe and evaluate the strategic environment of the modern nominating process, federal campaign finance law, the rise of presidential candidate PAC s, and the financial advantages of PAC sponsorship. Concluding chapters cover developing campaign organizations and fundraising programs, how PAC $s$ and political candidates used loopholes in the Federal Election C ampaign act to circumvent its requirements, assessments of thenrecent campaign finance reform proposals, and recommendations for reform in areas such as monetary expenditures and enhancing public disclosure of campaign finance expenditures.

Corrado, A . (1993), Paying for Presidents: Public $\mathrm{F}$ inancing in $\mathrm{N}$ ational $\mathrm{E}$ lections, Twentieth $\mathrm{C}$ entury F und Press, N ew York, ISBN 0-87-78$1855,127 p$.

The impact of the Federal Election $C$ ampaign Act and its provision providing for public financing of presidential elections is presented. An introduction examines current issues and trends affecting this subject such as the rising campaign expenditures and the IRS' checkoff provision on federal income tax returns as a revenue generating source for this program. Chapter contents examine subjects such as public financing of presidential elections, primary and general election campaign financing, and the future of campaign finance reform. Specific topics covered within these chapters include the declining number of taxpayers using the tax form checkoff, the minimal costs for breaking F ederal E lection C ampaign Act provisions, increasing soft money expenditures by both parties, and the need for Congress to adopt further restrictions on PAC giving and soft money. The study is supplemented with statistical charts.

Eismeier, T.J. and Pollock, P.H . III (1988), $B$ usiness, $M$ oney, and the R ise of $C$ orporate PACs in A merican Elections, Quorum Books, Westport, CT, ISBN 0-89930-322-6, 122p.

Eismeier and Pollock study and analyze the role of corporate PAC s in the electoral progress. $C$ hapter contents emphasize business in A merican politics, an organizational perspective on corporate PACs, regulatory politics and PACs, the political geography of corporate PACs, and corporate PAC s in election campaigns. Issues also presented include the role of ideology in corporate PAC activity, support of congressional incumbents by party, efforts of corporate PACs to influence regulatory activity through campaign contributions, sectoral breakdowns of corporate PACs, and PAC contributions by state. C oncluding assessments examine the possible influence of contribution limits on PAC activity, the declining pace of corporate PAC formation, and the growing role of states in regulatory activity and how this might affect future corporate PAC contributions.

G ais, T. (1996), I mproper I nfluence: C ampaign F inance $L$ aw, Political Interest $G$ roups, and the Problem of Equality, $U$ niversity of $M$ ichigan Press, Ann Arbor, ISBN 0-4721-06317, 236p.

$G$ ais analyzes the role of PAC $s$ which he contends proliferated after FECA's enactment in the early 1970s. He argues that campaign finance is the least inclusive area for grassroots political participation despite being the most regulated form of political activity. Following an 
introductory overview on the influence of PAC s and PAC contributions, $G$ ais presents chapters profiling and documenting institutions and biases in the PAC system, PAC formation among interest groups, and the interrelationship among PAC s, interest groups, political parties, and public policies. A conclusion proposes numerous recommendations for reform including deregulating PAC fundraising by increasing or eliminating the size of maximum individual contributions to PACs and relaxing tax and other laws prohibiting nonprofit nongovernmental organizations from engaging in electoral activity or from making grants to organizations engaging in electoral activity (pp. 183-4).

K au, J.B. and Rubin, P.H . (1982), Congressmen, $C$ onstituents, and $C$ ontributors: $D$ eterminants of $\mathrm{R}$ oll Call Voting in the $\mathrm{H}$ ouse of $\mathrm{R}$ epresentatives, $M$ artinius N ijhoff, Boston, ISBN 0-893980707, 160p.

$\mathrm{K}$ au and Rubin analyze what they see as economic factors contributing to roll call votes within the U S H ouse of R epresentatives. W riting from the perspective of economists who are generally critical of governmental regulation, $\mathrm{K}$ ay and Rubin examine and quantify factors they see influencing the votes of $\mathrm{H}$ ouse members. Study contents stress factors such as economic analysis and the rise of governmental economic regulation, class interest as a theory of legislative voting, characteristics of congressional roll call voting, the role of public interest lobbies in congressional voting, and ideological influences on minimum wage votes. Additional material examined includes the influence of ideology and logrolling in vote analysis, relations between laws and interest groups, and the role of PAC s in the 1972 and 1978 elections. $T$ he conclusion maintains that labor unions are the most effective actors in the political process and that the political contributions of businesses are less successful in influencing recipients votes (p. 122).

K ubiak, G . (1994), The G ilded D ome: TheU S Senate and Campaign F inance R eform, $U$ niversity of O klahoma Press, N orman, ISBN 0-80612621-3, 294p.

Provides coverage of proposed campaign finance legislation in the U S Senate during the 1980s and 1990s. K ubiak, an assistant to former
Senator D avid Boren (D-OK), presents the efforts of Boren and others to enact what they saw as campaign finance legislation. Emphasis is given to Boren's efforts to restrict the power of PAC $s$ and his alliances with senators as ideologically diverse as John M CC ain (R-AZ) and G eorge $M$ itchell ( $D-M E$ ). G ilded D ome also mentions the role played by congressional staffers in influencing debate on this and other subjects as well as the opposition to Boren's initiatives by senators such as $M$ itch $M$ CC onnell (R-KY). Kubiak's analysis concludes with a listing of proposed campaign finance reforms including voluntary and flexible spending limits, cutting individual PAC contribution rates by 50 percent, and strengthening FEC enforcement powers and the role of political parties (pp. 286-7).

M agleby, D.B. and N elson, C.J. (1990), The $M$ oney $C$ hase: $C$ ongressional $C$ ampaign $F$ inance R eform, $T$ he Brookings I nstitution, Washington, DC, ISBN 0-8157-5434-5, 227p.

The authors examine various issues involved in congressional campaign finance reform. Topics addressed in the first section include rules, practices, and partisan expectations of campaign finance reform, campaign costs, fundraising and campaign expenditures, political action committees, and the role of political parties and the Federal Election Commission. The second half examines changing contribution limitations, public financing, spending limitations, incentives and subsidies for improving competition, and simplifying campaign law administration. The concluding analysis mentions current problems, prospects, and consequences of congressional campaign finance reform in the early 1990s. A ppendices list statistical data sources and scenarios for hypothetical funding reform proposals.

M albin, M . J. and G ais, T. L. (1998), TheD ay A fter R eform: Sobering $C$ ampaign $F$ inance $L$ essons from the A merican States, T he R ockefeller Institute Press, Albany, NY, ISBN 0-914341-55-3 pbk, 194p.

The authors cover state campaign finance reform laws and the consequences of implementing and administering these statutes. Subjects receiving coverage include discussion of the laws and agencies involved in state 
campaign finance reform legislation, procedures for implementing the regulatory structures needed to administer these statutes, public funding issues, how interest groups adapt to regulation, limits on political party campaign contributions in F lorida, Wisconsin, Washington, and $M$ innesota, sources enhancing political competition, and possible responses to the failure of implemented reforms. Also included are tables and charts with figures and explanations of various state campaign finance reform laws.

Regens, J.L . and G addie, R.K . (1995), The $E$ conomic $R$ ealities of Political R eform: Elections and the U S Senate, $C$ ambridge U niversity Press, $\mathrm{C}$ ambridge and $\mathrm{N}$ ew York, ISBN 0-5214-7468$\mathrm{X}, 121 \mathrm{p}$.

This study of U S Senate election financing emphasizes the role of the market. Within this framework, legislators receive financial contributions based on their institutional positions and perceived political vulnerability. Topics covered in individual chapters include the Senate's institutional evolution and the structure of campaign finance, trends in fundraising by senators, contribution strategies of corporate, labor, trade, and cooperative PAC s, the importance of spending in Senate elections, and the effect of proposed campaign finance reforms. Regens and $G$ eddie contend that reform proposals such as term limits and public financing of elections would disrupt the rent-seeking relationship between legislators and economic interests as well as face political and constitutional barriers to their implementation.

Sabato, L.J. (1989), Paying for E lections: The Campaign $\mathrm{F}$ inance Thicket, Priority Press Publications, N ew York, ISBN 0-87078-247-9, 93p.

O ne of the field's leading scholars analyzes campaign finance issues. Sabato begins by listing campaign finance problems such as declines in party politics and small contributors, soaring campaign costs that deter potentially qualified candidates from seeking office, and disclosure requirement loopholes as issues having little root in political corruption (p. 5). $H$ is analysis describes what he sees as a misplaced obsession with PAC s by campaign finance critics, how reform proposals such as spending ceilings are bad ideas, strengths and weaknesses of free political advertising proposals, the need to increase the financial flexibility of political parties, and reform ideas Sabato considers useful such as tax credits for political contributions, enhanced disclosure of contributions, restricting honoraria to members of Congress, and prohibiting the use of leftover campaign funds for retirement benefits.

Sorauf, F. (1992), Inside C ampaign F inance: $M$ yths and Realities, Yale U niversity Press, $\mathrm{N}$ ew $H$ aven, CT, ISBN 0-300-05726-1, 274p.

This study opens with the observation that A mericans hold contradictory views on campaign finance by rhetorically objecting to the role played by money yet as many as 20 million willingly contribute to election campaigns each election year ( $p .1)$. Sorauf's initial chapter provides a historical overview of twentieth century campaign finance placing particular emphasis on developments following the 1970s enactment of the $\mathrm{F}$ ederal $\mathrm{C}$ ampaign $\mathrm{F}$ inance Election Act. Subsequent chapters analyze the sources and sums of political contributions, the goals of contributors and candidates in the exchange of political contributions, the influence of PACs, and ambivalent attitudes about public funding of elections. Topics also covered include assessment of whether the campaign finance system needs reform, the agenda and political objectives of those advocating campaign finance reform, and prospects for the future of campaign finance.

Stein, R.M . and Bickers, K .N . (1995), Perpetuating the Pork B arrel: Policy Subsystems and A merican D emocracy, C ambridge U niversity Press, C ambridge and $\mathrm{N}$ ew York, ISBN 0-52148298-4, 232p.

This treatise examines the role of policy subsystems such as C ongress, interest groups, federal program beneficiaries, and federal and subnational government agencies in governing and the American political and electoral processes. Topics covered include possible relationships between policy subsystems and pork barrel spending, the geographic scope of domestic U S G overnment spending, PAC contributions and domestic assistance program distribution, and the role of pork barrel spending in congressional elections. A ppendices include a descriptive database of domestic assistance programs, 
federal departments and their distributive policy agencies, financial assistance programs by public law for the 99th and 100th congresses (1985-1988), and a listing of PAC s whose parent interest groups testified in congressional hearings grouped by public law and PAC coalition for the aforementioned congresses.

Wilcox, C. (1988), F inancing Congressional Campaigns, American Political Science Association, Washington, DC, ISBN 0-9156-5475-4, $56 \mathrm{p}$.

Wilcox begins with a historical overview of campaign finance. H e emphasizes the 1907 passage of the Tilman Act prohibiting banks and corporations from making political contributions from their treasuries to federal office candidates as the first serious attempt at campaign finance reform in this century (p. 3). He proceeds to discuss various issues and questions in campaign finance assessments such as factors influencing PAC contribution strategy, whether independent PAC expenditures subvert the campaign process, and the role of a candidate's personal financial resources in the electoral process. $L$ ater sections cover the role of data analysis in examining campaign finance and using such analysis to study and assess the roles played in campaign finance by factors such as campaign receipts, incumbent and challenger fundraising, party committees, PACs, individual contributions, and candidates as campaign fund sources, and possible relationships between PAC contributions and congressional roll-call votes.

\section{Internet resources-government agencies C alifornia. Secretary of State. \\ $<$ http://www.ss.ca/ gov/elections/elections.htm>}

T his is the agency responsible for administering $C$ alifornia State election laws. Contents include candidate filing requirements, voter registration information, state candidate campaign finance information, and ballot casting procedures. Additional material covered includes voter fraud information, election returns, the text of ballot initiatives and qualification procedures, and voter registration statistics by county with party breakdowns along with current and historical absentee ballot use. A link to 1998 C alifornia general election <http://Note98.ss. ca.gov/ $>$ is also featured.
Indiana Secretary of State. http://www.state.in. us/sos/elections/

This is the official Indiana State elections and campaign finance information source. T he site features information such as PAC committee reports including those for candidate and party PACs, and campaign finance reports schedules. Additional material sinclude a guide to Indiana PACs, a campaign finance manual, precinct election worker handbook, political sign requirements, and Indiana Election Commission minutes. A summary of I ndiana $\mathrm{G}$ eneral Assembly election legislation from 1995-1998 is included as is the Indiana $C$ ampaign $F$ inance $D$ atabase featuring detailed financial records on Indiana political candidates and their committees. An election resource guide for children includes election information suitable for school assignments.

U S C ongress. H ouse C ommittee on G overnment Reform and O versight. <http://www. house.gov/reform/>

This site features a section devoted to coverage of 1996 federal election fundraising scandals. This area includes the text of the committee's interim campaign finance investigation report whose contents include charges that federal agencies failed to seriously pursue election violation perpetrators and profiles of the roles played in this matter by individuals such as Johnny C hung, Charlie Trie, John $\mathrm{H}$ uang, and Indonesia's Riady family. Exhibits such as deposition transcripts from individuals such as Washington G overnor Gary L ocke are presented as is the contempt of $C$ ongress report filed against $A$ ttorney $G$ eneral Janet R eno for not appointing an independent counsel to investigate the campaign finance scandal. T he site also features links to other committee hearings and reports on campaign finance along with RealV ideo coverage of their 4 A ugust 1998 campaign finance hearing.

U S C ongress. Senate. U S Senate L obby Registrations. <http://www. senate.gov/other/lobby/ lobby.htm>

Lobbying is an important factor in the A merican political process. The contents of this site describe the rules and regulations required to lobby both houses of $C$ ongress. T he site features material providing guidance from the 
L obbying D isclosure Act (LDA) of 1995 (Public $L$ aw 104-65). Available information covers definitions of lobbying, lobbying registration procedures, semiannual reporting of lobbying activities, how LDA relates to other statutes, LDA's public access provisions, and penalties for noncompliance with LDA provisions. Lobbying registration and semiannual report forms are included as is the text of LDA.

U S C ongress. Senate C ommittee on G overnmental Affairs. <http://www.senate.gov /-gov_affairs/>

This site features the text of the committee's report on its 1996 campaign finance scandal investigation the 1996 campaign finance scandal whose print version has al ready been annotated in this writing.

US Federal Election Commission. <http://www. fec.gov/>

T his is the Web site for the federal agency responsible for enforcing US election laws. It contains an FEC organization chart, information on public funding of presidential elections, and a brochure explaining the legal ban on election contributions by foreign nationals. Financial information on incumbents and challengers for $\mathrm{H}$ ouse and Senate races is provided as are historical voter registration statistics. A graph of PAC s broken down by sectors such as corporate, labor, and trade from 1977 to the present is provided as is information on electronically filing reports. A particularly timely and useful feature is the ability to access contributions and reports filed by presidential and $\mathrm{H}$ ouse candidates within the last 48 hours. The site is an essential source for tracking campaign finance developments.

\section{Interest group WWW sites}

C enter for Responsive Politics. <http://www. crp.org/>

T his organization studies $C$ ongress and the role money plays in the political process. Site contents include a congressional travel database searchable by member, staffer, and travel location, campaign contributor information, reports on 1998 election fundraising, and soft money contributions of over $\$ 200$. Additional materials include contributors of over $\$ 200$ arranged by zip code and employer, a database of 1995-1996 White H ouse coffee and sleepover participants, and campaign finance information on potential 2000 presidential candidates such as John A shcroft, D an Quayle, Dick G ephardt, and AI Gore.

Common Cause. <http://www.commoncause. org/>

This nonpartisan and nonprofit lobbying group advocates what it views as open, honest, and accountable government. This site contains campaign finance and open government information including reports and legislation as well as Federal Election Commission actions on campaign finance issues. Additional materials include selected corporate contributor information and recorded votes of individual members of $C$ ongress on campaign finance issues. Top soft money donors by parties, individual election cycles, and corporate sectors are also included.

Project Vote Smart. <http://www.vote-smart. org/>

Information on this site, one of the most authoritative of all political WWW sites, includes the text of state ballot initiatives, state legislative district maps, locations of county voter registration offices, and diverse interest group ratings of members of $C$ ongress. The most important section of this site is the $\mathrm{N}$ ational Political Awareness Test which asks participating state and federal candidates detailed questions and records their answers on a variety of public policy issues.

\section{Public C itizen. <http://www.citizen.org/ congress/>}

This site from $\mathrm{R}$ alph $\mathrm{N}$ ader's leftist-oriented Public C itizen contains information about congressional activity on issues of concern to this organization such as campaign finance reform, tobacco legislation and litigation, ethics and congressional reform, and their view of corporate welfare. C ongressional votes on these and similar issues are also documented on this site.

\section{Political Action Committee WWW sites}

A merican Federation of $L$ abor-C ongress of Industrial Organizations (AFL-CIO) $<$ http://www.aflcio.org/>

The principal site of leading U S labor union, this site features information on voting records 
of members of $C$ ongress on organized labor issues, union organizing, organizing, business executive pay information, and press releases detailing A F L-CIO activity.

A merican I srael Public Affairs C ommittee (AIPAC) <http://www.aipac.org/>

This organization lobbies for pro-Israel legislation and against what it considers anti-I srael legislation in Congress. T he site features links to legislation on relevant issues such as urging an override of President C linton's veto of the I ran M issile Proliferation Sanctions Act, links to I sraeli sites, and information on M iddleE astern developments.

\section{Black A merica's Political Action Committee} (BAM PAC) <http://www. bampac.org/>

T his political action committee headed by 1996 Republican presidential candidate A lan K eyes seeks to promote the election of black conservatives to local, state, and federal offices. Information on this site includes listings of BAM PAC supported candidates, organizational issues stances, speeches by K eyes, and links to various conservative WWW sites.

$C$ alifornia L eague of C onservation VotersE covote Online <http://www.ecovote. org/

This organization is dedicated to promoting environmental issues and supporting candidates it sees as responsive to their interests. The site contains lists of candidates for $\mathrm{C}$ alifornia state and federal office which they endorse, a scorecard of C alifornia state legislators on environmental legislation, listings of $\mathrm{C}$ al ifornia state environmental legislation by subject and the L eague's position on these bills, and critical evaluations of the environmental positions of $C$ alifornia gubernatorial and U S Senate candidates $D$ an $L$ ungren and $M$ att $F$ ong.

D efend America <http://www.defendamerica. com/dapac.html>

T his conservative political organization was founded by Senator Richard Shelby (R-AL) and is dedicated to electing conservative state and federal government officials. C ontents of site include biographical information on Senator Shelby, an organizational mission statement, information on how to support $D$ efend Ameri$\mathrm{ca}$, and links to state Republican Party and conservative WWW sites with particular emphasis placed on A labama sites.

Early M oney Is L ike Yeast (Emily's L ist) $<$ http://www.emilyslist.org/>

This political action committee is dedicated to electing pro-choice $D$ emocratic women candidates to state and federal offices. Site contents include the number of donors by state, women in state legislatures, the names of candidates it has successfully elected, and lists of recommended female candidates for the 1997-1998 election cycle. It features a newsstand with updates on recent political developments of interest.

Fight O rdinances and Restrictions to $C$ ontrol and Eliminate Smoking (F ORCES) <http:// forces.org/>

This group is dedicated to fighting anti-smoking legislation, litigation, and regulation in the U S. Site provides links to pro-smoking resources and materials pointing out what FORCES sees as weaknesses in the positions of anti-smoking advocates. It features information on how to lobby for organization issues, stances and links to state and foreign branches' sites of sympathetic individuals and organizations.

K ansans F or L ife (K F L) <http://www.kfl.org/>

This organization promotes pro-life positions on abortion and opposition to euthanasia in $\mathrm{K}$ ansas. T he site contains information about organization events, $\mathrm{K}$ ansas state legislative developments on issues of concern, and the voting records of K ansas' state and federal legislators on abortion issues.

$X$-PAC: T he Political Action Committee for G eneration X <http://www.freespeech. org/x-pac/>

This nonpartisan political action committee focuses on what it sees as the economic and political needs of $G$ eneration $X$ with particular emphasis on social security reform. The site features links to social security legislation, relevant congressional committees such as the Senate Budget $\mathrm{C}$ ommittee and $\mathrm{H}$ ouse Ways and $M$ eans $C$ ommittee, $G$ eneral Accounting O ffice reports on social security, and X-PAC financial disclosure statements filed with the FEC. 